\section{Mistä löytyy motivaatio?}

Salmela-Aro, Katariina \& Nurmi, Jari-Erik (toim.) (2017).

Mikä meitä liikuttaa. Motivaatiopsykologian perusteet.

3. uudistettu painos. PS-Kustannus. 250 sivua.

KIRJA KANNUSTAA LUKIJAA tutustumaan motivaation merkitykseen yksilön ja yhteisön näkökulmasta. Siinä esitellään monipuolisesti erilaisia lähestymistapoja motivaatiopsykologiaan ja sen soveltamiseen käytännössä. Lukija saa uutta tietoa motivaation merkityksestä hyvinvoinnille niin henkilökohtaisessa elämässä kuin työelämässä.

Teos on jaettu kolmeen osaan. Niissä käsitellään näkökulmia motivaatiotieteeseen ja keskeisiä motivaatioteorioita, motivaation vaikutukseen työnteossa sekä motivaation ja hyvinvoinnin yhteyttä. Artikkelikokoelmassa esitellään motivaatioon liittyviä ilmiöitä ja teoreettisia näkökulmia parinkymmenen tutkijan ja asiantuntijan voimin.

\section{MOTIVAATION MERKITYS}

Motivaation merkitystä mielekkääseen elämään ei voi väheksyä, ja motivaatiotieteen perusteos avaa teemaa havainnollisesti. Kirjoittajat kuvaavat kiinnostavalla tavalla tämän päivän motivaatiotieteellistä ajattelua, joka yhdistää negatiivisen ja positiivisen lähestymistavan motivaatiopsykologiaan. Näkökulmien yhdistäminen nostaa esiin uuden keskeisen ulottuvuuden ihmisen motivaation sekä toiminnan ja hyvinvoinnin tarkasteluun. Se konkretisoituu erityisesti suomalaisille lukijoille sisuna: siinä yhdistyvät positiivinen ja negatiivinen motivaatio, jotka auttavat saavuttamaan pitkän tähtäimen tavoitteita.

Unelmointi yksin ei edistä tavoitteiden saavuttamista, vaan lisäksi tarvitaan ymmärrystä unelmien saavuttamista koskevista haasteista. Se taas lisää ymmärrystä siitä, miten esteet voitetaan.

Työelämä vaatii jatkuvaa uuden opettelua ja uuden luomisen kykyä, samoin työntekijöiltä vaaditaan sisäistä motivaatiota. Kirjassa tuodaan esille, että sisäisesti työstään motivoituneet ovat usein merkittävästi luovempia ja oppivat nopeammin ja syvemmin kuin ulkoisesti motivoituneet. Mielekäs ja henkilökohtaisesti merkityksellinen työ auttaa ottamaan vastaan uusia haasteita ja uudenlaisten ongelmien ratkaisuja. Mutta työmotivaatioon vaikuttavat muutkin seikat, kuten sosiaalinen ympäristö. Haluamme kokea yhteenkuuluvuutta ja tulla hyväksytyksi. Perheellä, ystävillä sekä työyhteisöllä on merkitystä motivaatioomme.

\section{HYVINVOINNIN \\ MOTIVAATIOMALLI}

Itseohjautuvuus, yrittäjähenkisyys, sisäinen motivaatio ja jatkuva oppiminen tunnistetaan tulevaisuuden

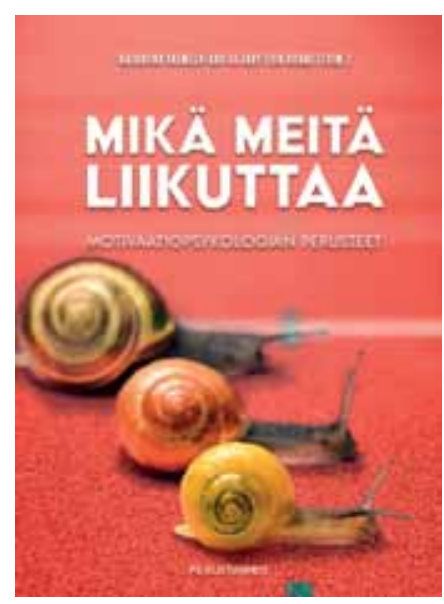

työelämän taidoiksi, mutta löydämmekö niitä itsestämme? Perintötekijät ja ympäristö vaikuttavat yksilöiden välisiin eroihin erilaisten tavoitteiden ja tulevaisuuden suunnitelmien asettamisessa. Henkilökohtaisten tavoitteiden avulla ihmiset suuntaavat omaa elämäänsä sosiaalisessa ympäristössä. He sopeuttavat, muokkaavat ja kompensoivat tavoitteitaan esiin tulevien vaatimusten ja palautteen mukaisesti. Kirjassa esitellään motivaatiotutkimuksen teorioita ja teoreettisia näkökulmia, kuten elämänkulun $4 S$-motivaatiomallia: Se vaikuttaa henkilökohtaisten tavoitteiden saavuttamiseen ja sen avulla voidaan selvittää yksilöiden motivaatiota ja sen muutosta elämän eri vaiheissa. Neljä prosessia - suuntaaminen, suunnistaminen, sosiaalinen säätely ja sopeutuminen - liittyvät yhteissäätelyn muodossa elämän eri vaiheisiin kohdatessamme haasteita, vaatimuksia ja mahdollisuuksia sosiaalisessa ympäristössä. Toteutamme motivaatiotamme sosiaalisessa 
kontekstissa yhdessä muiden kanssa. Merkittävät elämän siirtymät, kuten vanhemmaksi tuleminen tai eläköityminen, suuntaavat motivaatiotamme. Näin tavoitteet muuttuvat siirtymän haasteiden mukaisesti eri-ikäisillä ja eri kulttuureissa eri tavoin.

\section{SISÄISEN MOTIVAATION METSÄSTYS}

Kirjoittajat toteavat, että oppimisen näkökulmasta motivaation lähde on olennaisempaa kuin sen määrä. Sisäinen motivaatio edistää oppimista, sillä se lisää positiivisia tunteita oppimista kohtaan sekä johtaa luovuuteen, sinnikkyyteen ja syvempään käsitteiden sisäistämiseen. Oppimista parantavat uusimpien tutkimusten mukaan vanhempien ja opettajien emotionaalinen tuki ja rohkaisu itsenäisyyteen. Ulkoa tulevat vaatimukset eivät siis motivoi riittävästi.

Kirjassa tuodaan esille näkemys työelämästä, joka haastaa tulevien sukupolvien käytössä olevat henkilökohtaiset voimavarat ja työnteon syyt. Uudet sukupolvet sopeutuvat muuttuneisiin työoloihin tai pyrkivät muuttamaan niitä tarpeitaan ja tavoitteitaan vastaaviksi. Työntekijöitä houkuttelee työn imu, eli pysyvä, myönteinen tunne- ja motivaatiotila. Se syntyy sisäisen motivaation avulla ja il- menee tarmokkuutena, omistautumisena ja uppoutumisena työhön. Tehokkuuteen vaikuttavat lisäksi oikeudenmukaisuuden kokemukset ja se, että esimerkiksi lähiesimies voimaannuttaa, kannustaa ja toimii esimerkkinä.

\section{KOLME PSYKOLOGISTA PERUSTARVETTA}

Kirjassa esitelty itsemääräämisteoria ja sen merkitys työhön on innoittavaa luettavaa. Sen mukaan ihmisellä on kolme psykologista perustarvetta: autonomia, kyvykkyys ja yhteenkuuluvuus. Ne vaikuttavat hyvinvointiimme, kasvuumme ja sisäsyntyisen motivaation kokemiseen. Esimerkiksi autonomian tukeminen ja palautteen antaminen vahvistavat työntekijöiden kokemusta perustarpeiden tyydyttämisestä ja aiheuttavat positiivisia hyvinvointi- ja suoriutumisvaikutuksia.

Perustarpeiden toteutuminen on tulevaisuuden työelämässä tärkeää, jotta yksilö ja työyhteisö voivat toimia menestyksekkäästi. Sisäisen motivaation merkitys on suuri - sen avulla yksilöiden toiminta on tuloksellista, laadukkaampaa ja vaikuttaa positiivisesti myös heidän hyvinvointiinsa. Tulevaisuuden työelämässä perustarpeiden toteutuminen on välttämättömyys samalla kun yksilöiltä edellytetään jatkuvaa uudistumiskykyä. Vaativassa työelämässä tarvitaan henkilökohtaisia voimavaroja, kuten motivaatiota. Kirja nostaakin esille kysymyksiä siitä, miten motivaatioon voitaisiin vaikuttaa.

Kirjan monia oppeja voidaan hyödyntää käytännön elämässä. Kouluttajana mietin paljon motivaation merkitystä aikuisten oppimisessa: Millaiset asiat motivoivat ja miksi? Miksi ihmisillä on erilaisia tavoitteita ja pyrkimyksiä? Miten työyhteisö voi huolehtia työntekijän motivoinnista eri elämänvaiheissa?

Kirja vastaa moniin kysymyksiini ja tuo lisää tietoa motivaatiotutkimuksen teorioista. Se on helposti luettava, selkeä ja asiapitoinen kokonaisuus.

\section{SANNA JUVONEN}

$\mathrm{KM}$, lehtori

Laurea-ammattikorkeakoulu 